\title{
Relationship Between Perception of Service Quality and Students' Satisfaction - A Case Study of a Management School
}

\author{
Rojan Baniya* \\ School of Management, Kathmandu University, Lalitpur, Nepal
}

\begin{abstract}
This study examines the relationship between service quality dimensions (SERVQUAL Model) and overall service quality and satisfaction of management students. Additionally, this study identifies critical factors amongst service quality dimensions that contribute most to students' satisfaction. Furthermore, this study examines whether the relationship between overall service quality and student satisfaction is valid at both Bachelor in Business Administration (BBA) level and Master in Business Administration (MBA) level. Self-administered online surveyswere conducted among the undergraduate and graduate students of a management school in Kathmandu to collect the data, which were analysed using correlations and regressions. Both 'dimensions of service quality' and 'composite service quality construct' had positive relationship with students' satisfaction, such that at both graduate and undergraduate level, service quality is antecedent of students' satisfaction. Among the dimensions of service quality, empathy and responsiveness were found to be significant predictors of service quality. The empirical results of this study attest to Parasuraman, Zeithaml, and Berry's (1985) SERVQUAL. This study also provides a basis for further validation of relationship between service quality and student satisfaction in future. Finally, itsuggests management schools to improve their service quality,and its various dimensions, leading to students' satisfaction.
\end{abstract}

Keywords: Service Quality; Student Satisfaction; Tangibility; Reliability; Responsiveness; Assurance; Empathy

\section{Introduction}

Nepal has witnessed significant growth of management schools in recent years. The growing importance of management education was well understood with prediction for it to hold the topmost position in terms of enrolment and all other important aspects (Acharya, 2009). Indeed, Nepal holds tremendous promise for management education, which can be foreseen by the demand for management graduates from ever growing service sectors, other

* Author email: rojan@kusom.edu.np

ISSN: 2091-0118(Print)/2091-2560(Online)

(C) 2016 JER 
emerging sectors like hospitality, hydro and business organizations, and alsodue to the entry of a growing number of multinational companies (Koirala, 2005). Nevertheless, the significant increase in the number of management schools also poses strong competition among themselves, which requires them to critically look into how they maintain service quality that leads to students' satisfaction.

In today's competitive management education environment, where students have the choices of institutions (like local private, local public, neighbouring country and/or western country institutions), the facets that enable management education institution to draw and retain these students is of great interest. Similarly, the demand for professionally qualified managers surged with liberalized policies in Nepal, which invites private sectors to run management schools (Katuwal, 2011). The involvement of private sector is visible through an increased number of private management schools (Kraft \& Vodopoviec, 2003). However, with the large number of management schools, the quality of management education did not enhance (K.C., 2014). The consequence of low quality management education (K.C., 2014) has been resulting in more and more students opting for abroad studies. This has affected management schools in Nepal in attracting and retaining students. In resulting effect, management schools are going on the road to competition and are also obligated to boost their quality (Katuwal, 2011). Students now have options to get into another management institution around the corner or opt for foreign management schools.

Students who have wide-ranging offers for management education both internally and externally to study in are becoming more critical. On top of that, amidst tough competition, management institutions are marred by various problems. No wonder, the question about the service quality and student satisfaction of management institutions is also raised. Consequently, more and more Nepali management students are attracted to foreign management schools. This is well illustrated by the increasing annual trend of Nepali students migrating to foreign universities for higher education (Katuwal, 2011). Research indicates that students are increasingly becoming critical and analytical when they choose a university (Bindsardi \& Ekwulugo, 2003). Under the given circumstances, it is safe to presume that students' expectations are not fulfilled by the institutions and therefore it has become the key factor for students' withdrawal (Alridge \& Rowley, 2001). All these demand that Nepali management institutions be well awareto serve best to their students who are their 'primary customers (Gruber, Fuß, Voss, \& Gläser-Zikuda, 2010; Hill, 1995).

Higher education institutions are involved in increasingly intense struggle to attract new students by claiming that they offer quality education (Nicholls, Harris, Morgan, Clarke, \& Sims, 1995; Soutar \& Turner, 2002). Seriously affected by small domestic market size, management education in Nepal has a lot to improve in quality and competitiveness (Rosenbloom \& K.C., 2005). Given all these, it is now more required than ever for management institutions to be aware of their service quality and student satisfaction. 
This brings to the premise of this study that students are central to management institutions' survival, sustainability, and growth. In this competitive market, satisfaction with services may make the difference because customer satisfaction is also based upon the level of service quality provided by the service providers and service quality acts as a determinant of customer satisfaction (H. Lee, Lee, \& Yoo, 2000; Parasuraman, Zeithaml, \& Berry, 1996). Now, students can turn to lots of options for management education. Therefore, management institutions in Nepal can no longer be complacent about their performance and service quality standards. One of the areas of improvement is maintenance of high service quality to attract and retain students, who are the primary customers of any management education institutions. One way is to keeping students satisfied with the service quality offered (Wilson, Zeithaml, Bitner, \& Gremler, 2008).

There is scant information on service quality levels in Nepali management institutions, Nepali management students' satisfactions and their interrelations with service quality and its dimensions. Trying to fill this gap, this study aims to explain the relationship between service quality and student satisfaction. The study presents students' perspective about their own satisfaction with management institution they attend and its antecedents. There are similar studies that have been conducted in other cultural settings. However, it has been proven that evaluation of the service quality is influenced by culture, and also that the cultural characteristics of customers affect the importance of service quality dimensions (Dash, Bruning, \& Acharya, 2009). Thus, other similar studies can only indicate, but cannot provide clear picture on the way Nepali students evaluate service quality, importance of service quality dimensions and its relationship with satisfaction.

The major questions that the present study tries to investigate are - what relationship exists between service quality dimensions and satisfaction among the students of management education institutions and which critical factors in service quality contribute most to the satisfaction of students and which dimensions of service quality affect student satisfaction? In absence of the dimensions of service quality developed in the context of Nepal, this study uses dimensions of service quality called SERVQUAL proposed by Berry, Zeithaml, and Parasuraman (1990). Before going into these questions I first discuss some of the key concepts used, describe the conceptual framework, set the hypotheses, and discuss the methods adopted in carrying out this study.

\section{Student Satisfaction}

Any service provider would like to see their customers satisfied. Customer satisfaction may be one of the most sought out outcome after delivery of any products or services. In academic research as well as in marketing practices, customer satisfaction has remained the center of discussion since Cardozo (1965) conducted his preliminary study of customer efforts, expectations and satisfaction. Over the period, a wide variety of definitions and conceptualizations of satisfaction have taken place; however, they have failed to reach a 
common consensus. Nevertheless, the most widely accepted one is based on the expectancy disconfirmation theory (McQuitty, Finn, \& Wiley, 2000) developed by Oliver (1980), who proposed satisfaction level to arise from the discrepancy between expected and perceived performance. Students form certain expectations about academic institutions based on various factors like word-of-mouth, reputation, comparative analysis, etc. When they actually attend the institution, they perceive the performance through real experience and form post consumption evaluative judgment. Student satisfaction (positive disconfirmation) transpires if service quality of the institution is better than expected. On the other hand, if the performance of the institution turns out to be worse than expected, dissatisfaction (negative disconfirmation)results.

Satisfaction is the main agenda of both academic and non-academic institutions all around the world. This is the fact that satisfaction influences performance at both individual and organizational level (Cranny, Smith, \& Stone, 1992; DeCenzo \& Robbins, 2010). Studies have almost univocally shown that satisfaction provides benefits to firms in economic terms. Some studies associate customer satisfaction with the rise in revenue (Gómez, McLaughlin, \& Wittink, 2004; Rust, Zahorik, \& Keiningham, 1995). Similarly customer satisfaction leads to lower investments to get new customers and also reduction in other costs associated with poor quality, defects and complaints (Anderson, Fornell, \& Rust, 1997). Analysing these studies, customer satisfaction has been found to be a contributor to firm's economic well-being and progress. Thus, every organization wants to create a large pool of satisfied customers. Academic institutions, which are known more as social entity and whose delivery directly impacts people's future, cannot be in the position of having dissatisfied customers.

The first task for any academic institution is to identify factors affecting students' satisfaction; only then universities can improve on those factors. The phenomenon of increasing student satisfaction and their loyalty through improved service quality is becoming common in universities across the globe (Ijaz, Irfan, Shahbaz, Awan, \& Sabir, 2011).

\section{Service Quality}

Past studies have identified 'service quality' as a principal factor in the success of any business (Parasuraman et al., 1988) and the education sector in this case is not an exception. At the end of the day, educational institutions have toserve its customers present in the form of students, parents and community. A challenge for the researchers has been to convert the esoteric concept of 'service quality' into concrete dimensions that can provide actionable tools with performance parameters. An appreciable work in this area has been done by Gronroos (1983), U. Lehtinen and Lehtinen (1982), and Parasuraman et al. (1985), whose works attempt to uncover the factors that determine service quality. 
Long ago, Sasser, Olsen, and Wyckoff (1978) introduced seven distinct service attributes (security, consistency, attitude, completeness, condition, availability, training) with a supposition to enfold the concept of service quality. Gronroos(1983) proposed three dimensions of service quality: technical quality related to outcome, functional quality related to customer meet, and corporate image as outcome. Similar three dimensions of quality emerged from U. Lehtinen and Lehtinen (1982) - physical quality, interactive quality and corporate quality. Most of the service businesses involve active customer engagement. A commonality among these researchers exists that the service quality needs to be viewed from two distinct aspects - process of service delivery and outcome of service as perceived by the customers (Kitchroen, 2004).

Many other attempts to establish the determinants of service quality were made, as service quality became an important area of interest to researchers. Efforts were put in to find those dimensions that could be generalised across any type of service. Parasuraman et al. (1985) lodged ten such determinants of service quality. On further investigation, Parasuraman et al. (1988) detected overlaps among the ten dimensions (tangibles, reliability, responsiveness, communication, credibility, security, competence, courtesy, understanding/knowing the customers and access) and trimmed them into a list of five dimensions (tangible, reliability, responsiveness, assurance and empathy). This is widely known as SERVQUAL model.

Service quality is defined as "the degree and direction of discrepancy between customers' service perceptions and expectations" (Parasuraman et al., 1985). Thus, this definition leads to three state of service quality: if customers' service perception is lower than expectation, low service quality is experienced, if it equals then moderate service quality is offered, and finally if the service quality perception exceeds the expectation, high service quality is discerned.

\section{SERVQUAL and Its Dimensions}

SERVQUAL is a widely popular measure of 'service quality' that compares the disparity between customer's perception and expectation from service business along five defined dimensions - tangibles, reliability, responsiveness, assurance and empathy (Nitecki, 1996). Disconfirmation of Expectations Paradigm (Patterson 1993) forms the basis for this comparison. In clear terms, comparison process works in the following semantics:

- Perceived Performance > Expectation: High Satisfaction

- Perceived Performance = Expectation: Satisfaction

- Perceived Performance < Expectation: Dissatisfaction

The five dimensions of SERVQUAL measure service quality across all the service sectors and provide a foundation for service-quality domain upon which items were derived for SERVQUAL scale (Parasuraman et al., 1988). The scale stands on sound conceptual underpinnings whose concise dimensions are given below: 
48 R. Baniya

Tangibles: $\quad$ Physical facilities, equipment, and appearance of personnel

Reliability: Ability to perform the promised service dependably and accurately

Responsiveness: Willingness to help customers and provide prompt service

Assurance:

Knowledge and courtesy of employees and their ability to inspire trust and confidence

Empathy: $\quad$ Caring, individualized attention the firm provides its customers

Over the time, several other developments have been made, as well as other propositions to measure service quality like SERVPERF by Cronin and Taylor (1992) have come out. The truth is "work on service quality can best be described as divergent" (Brady \& Cronin 2001). Nevertheless, SERVQUAL stands out as the presiding model used for appraising service quality (Buttle, 1996; Robinson, 1999; Woo \& Ennew 2005).

Past studies have used SERVQUAL to assess service quality of business schools (Rigotti \& Pitt, 1992) and higher educational institutions (Saaditul, Samsinar, \& Wong, 2000). Various studies have found different dimensions of SERVQUAL to be of variable importance when linked with student satisfaction. Cuthbert (1996) found tangibility (3.34) to be the highest, followed by assurance (3.21), reliability (3.11), responsiveness (3.04) and empathy (2.58). O'Neill and Palmer (2004) found similar rankings. However, Perisau and McDanier (1997) had different conclusion, where assurance and reliability were given the highest grade. The lack of uniformity in student's ranking over the importance of dimensions of SERVQUAL is visible from these studies. In the Nepali context, which enjoys its own blend of culture and values, the relative importance of the SERVQUAL dimensions may vary and may not be consistent with the findings in other cultural settings. This makes the study relevant and interesting from the research perspective.

\section{Service Quality and Students' Satisfaction}

Satisfaction is the state that any organization wants to transpire its customers to. Companies intentionally perform to content their customers to the position of satisfaction (Malik \& Usman, 2011). For any service institution, understanding determinants of customer satisfactions is important to remain competitive (Lassar, Manolis, \& Winsor, 2000). For academic institutions too, satisfaction of its customers is important, and thus to understand determinants of customer satisfaction is even more important. Conventionally, perceived service quality has been well established as an antecedent to satisfaction (Spreng $\&$ Mckoy, 1996). As for any other institution, for academic institution also, one of the criteria for student satisfaction remainsthe same, i.e. perceived service quality.

Several studies have found significant relationship between service quality and satisfaction. Bigne, Moliner, and Sanchez (2003) in their study stated that satisfaction hasa significant relationship with the overall service quality. With similar results in higher education institutions, Ham and Hayduk (2003) went further to analysethe relationship based on each of the dimensions of service quality and found that reliability exhibited the 
strongest relationship followed by responsiveness, empathy, assurance and tangibility. The SERVQUAL framework has served well in identification of service quality and building relationships with other critical variables.

There are studies that have taken their own dimensions to measure the determinants of satisfaction in academic institutions. The top three highly significant variables that impact overall satisfaction of the university were excellence in instruction in major, able to get desired classes and knowledgeable advisors (Elliot \& Shin, 2002).

Deriving from Parasuraman et al. (1988), this paper draws its theoretical framework as below:

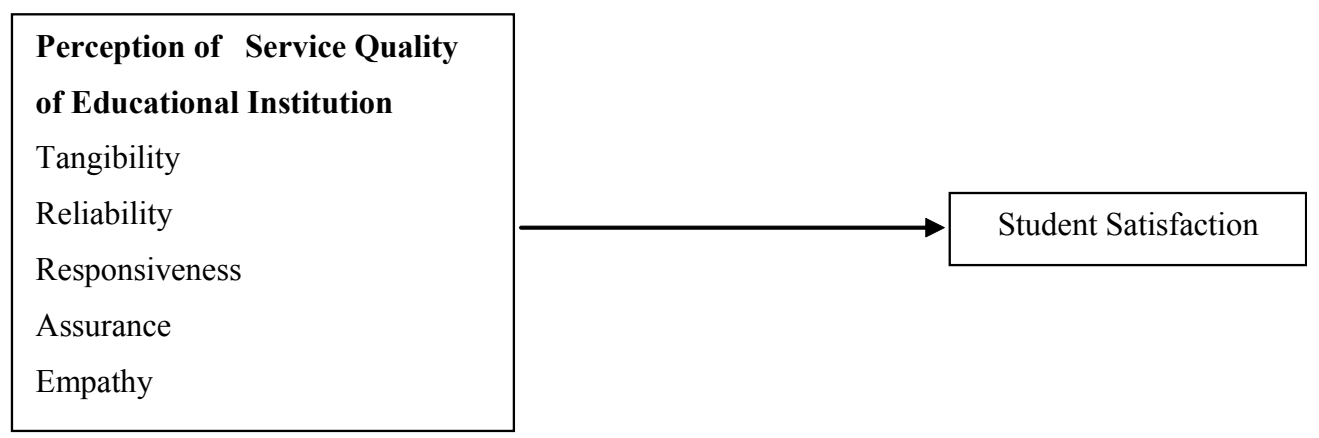

Figure 1. Theoretical framework.

\section{Research Hypotheses}

This study proposed following hypotheses:

H1: Student Satisfaction is positively related to service quality.

$\mathrm{H} 2$ : Student Satisfaction is positively related to tangibility.

H3: Student Satisfaction is positively related to reliability.

H4: Student Satisfaction is positively related to responsiveness.

H5: Student Satisfaction is positively related to assurance.

H6: Student Satisfaction is positively related to empathy.

H7: The relationship between student satisfaction and service quality and its

determinants does not vary among graduate and undergraduate students.

\section{Methods}

The population of this study comprised students enrolled in the MBA and BBA programmes in management colleges. The nature of data was quantitative collected through self-administered online questionnaire. The study setting is non-contrived and individual graduate and undergraduate students are the units of analysis. This study is a single cross-sectional study. Purposively, a management college with a large population of 700 management students was selected and then students from that college were selected on a random basis. 
$50 \mid$ R. Baniya

Already validated instruments were used for capturing study variables, which was contextualized to local context during pre-testing with slight modification in language. For assessing service quality, Parasuraman et al.'s SERVQUAL model with five dimensions - (1) tangibility, (2) reliability, (3) assurance, (3) responsiveness, and (4) empathy was selected. This scale has 46 items, where tangibility dimension was captured by sixteen items; reliability dimension by nine items and rest of the three dimensions by seven items each (Parasuraman et al., 1985). Overall student satisfaction with higher educational institutions plays the role of the dependent variable in this study (Bigne et al., 2003).

The instrument to measure service quality using the five dimensions was adopted from Parasuraman and colleagues (i.e. Parasuraman et al., 1985; Parasuraman et al., 1988; Berry et al., 1990) taking help of LeBlanc and Nguyen (1997) for some items. Likert scale ranging from 1 (for 'not satisfied') to 6 (for 'very satisfied') was used. A six scale Likert instrument was adapted from Atheeyaman (1997) to measure the satisfaction level of the students - ranging from 'one' (for 'much worse than expected') to 'six' (for 'not much better than expected'). The mean score of each scale was calculated by adding the scores on each individual item of the scale and taking the mean of the sum. Pre-testing was done to ensure the validity of the instrument, which ensured that the data collected were sufficiently sound, relevant and consistent. For the purpose of assessing the internal consistency of the scale, Cronbach's alpha was computed. And the alpha coefficient of the scales ranged from .77 (Responsiveness) to .92 (Student Satisfaction).

In the population of seven hundred management students at the graduate and undergraduate levels (BBA and MBA), questionnaires were distributed to randomly selected students of Kathmandu University School of Management. The sample included graduate and undergraduate level management students, who have spent at least one year in themanagement school. Ethical guidelines were followed during the data collection and analysis, where the participants remained anonymous and the participation was voluntary, based on informed consent. Altogether, 286 questionnaires were returned, out of which 241 were found usable. The rest of the returned forms were rejected because of missing data. Among those 241 students who returned the completed questionnaires, fifty-five percent were female, seventy-five percent were from undergraduate programs, and their mean age was 21 .

This study has several limitations that need to be addressed in future research. First, all the study variables were captured from self-reported measures and therefore self-report bias cannot be ruled out. Second, the samples for this study were drawn from one management school. Sample drawn from one management school restricts the representativeness of the sample. Nonetheless, the findings of this study are in line with the findings of the studies carried out in different educational and cultural contexts suggesting the validity and generalisability of the study. 


\section{Findings of the Study}

The analysis of the survey data supportedthe associations between different dimensions of service quality and student satisfaction. In line with this, the major findings of the study is presented below.

\section{Correlation Between Service Quality, Its Dimensions and Student Satisfactions}

Pearson correlation coefficients between study variables as well as their mean, standard deviation, and internal consistency reliability (Cronbach's alpha) are shown in Table 1. The data showed that the mean of student satisfaction was (3.92 on a 6-point scale) followed by service quality with an overall mean of 4.88 (on a 6-point scale) which shows that students are satisfied with the overall service quality. For each dimension, assurance scored the highest (5.89 on a 6-point scale), followed by empathy (5.57 on a 6-point scale), reliability (5.43 on a 6-point scale), tangibility and responsiveness (5.19 and 5.00 on a 6-point scale). As indicated in the table, satisfaction was positively related to service quality, tangibility, assurance, empathy, reliability and responsiveness $(\bullet=.63, \mathrm{p}<.01 ; \bullet=.47, \mathrm{p}<.01 ; \bullet=$ $.58, \mathrm{p}<.01, \bullet=.57, \mathrm{p}<.01, \bullet=.53, \mathrm{p}<.01, \bullet=.58, \mathrm{p}<.01$, respectively).

Table 1

Mean, Standard Deviation, Correlation Matrix, and Cronbach's Alpha

\begin{tabular}{llccccccccc}
\hline & & Mean & SD & 1 & 2 & 3 & 4 & 5 & 6 & 7 \\
\hline 1 & Satisfaction & 3.92 & 1.06 & .92 & & & & & & \\
2 & SQ & 4.88 & 0.60 & $.63^{* *}$ & .91 & & & & & \\
3 & Tangibility & 5.19 & 0.79 & $.47^{* *}$ & $.85^{* *}$ & .88 & & & & \\
4 & Assurance & 5.89 & 1.21 & $.58^{* *}$ & $.91^{* *}$ & $.77^{* *}$ & .86 & & & \\
5 & Empathy & 5.57 & 0.83 & $.57^{* *}$ & $.86^{* *}$ & $.65^{* *}$ & $.68^{* *}$ & .80 & & \\
6 & Reliability & 5.43 & 0.90 & $.53^{* *}$ & $.86^{* *}$ & $.65^{* *}$ & $.78^{* *}$ & $.62^{* *}$ & .82 & \\
7 & Responsiveness & 5.00 & 0.70 & $.58^{* *}$ & $.84^{* *}$ & $.60^{* *}$ & $.72^{* *}$ & $.71^{* *}$ & $.63^{* *}$ & .77 \\
\hline
\end{tabular}

Note: $* * \mathrm{p}<.01$

SQ - Service Quality

Cronbach's alpha values are shown in diagonal

The above result indicated that all the relationships between different study variables were significant and in the expected directions. However, as these correlation analyses are the measure of associations between variables, they are not robust enough to test the proposed hypotheses. Therefore, regression equation was estimated to assess the relationships between Satisfaction and Service Quality and its five dimensions (tangibility, assurance, empathy, reliability and responsiveness). 


\section{Dimensions of Service Quality and Students Satisfaction}

The results of regression analyses are shown in Tables 2 and 3.

Table 2

Simple Linear Regression Analyses Results

\begin{tabular}{clc}
\hline Model & & Standardized Coefficients \\
\hline \multirow{3}{*}{1} & & $\mathrm{~B}$ \\
& (Constant) & 0.61 \\
& Service_Quality & $0.63^{* *}$ \\
\hline \multirow{4}{*}{$\mathrm{R}^{2}$} & 0.40 \\
& Adjusted $\mathrm{R}^{2}$ & 0.39 \\
& $\mathrm{~F}$ & $146.55^{* *}$ \\
& $\mathrm{~N}$ & 241 \\
\hline
\end{tabular}

Note: Dependent Variable: Student Satisfaction; $* * \mathrm{p}<.01$

In Table 2, the results showed that $\mathrm{R} 2=0.39$ (adjusted $\mathrm{R} 2=0.39$ ), i.e. $39.5 \%$ of the variance in students' satisfaction was explained by service quality. The F statistics produced $(\mathrm{F}=146.55)$ was significant at the 0.00 level. From the result, it can be considered that service quality is an antecedent of students' satisfaction in the studied management institution.

Table 3

Multiple Regression Analyses Result

\begin{tabular}{llc}
\hline Model & & Standardized Coefficients \\
\hline 1 & (Constant) & 0.67 \\
& Tangibility & -0.04 \\
& Assurance & 0.21 \\
& Reliability & 0.11 \\
& Responsiveness & $0.18^{* *}$ \\
& Empathy & $0.27^{* *}$ \\
\hline & $\mathrm{R}^{2}$ & 0.41 \\
& Adjusted $\mathrm{R}^{2}$ & 0.40 \\
$\mathrm{~F}$ & $30.97^{* *}$ \\
$\mathrm{~N}$ & 241 \\
\hline
\end{tabular}

Note: Dependent Variable: Student Satisfaction; ${ }^{* *} \mathrm{p}<.01$

Table 3 shows that $R 2=0.41$ (adjusted $R 2=0.40$ ), which suggested that $41.3 \%$ of the variance in students' satisfaction was explained by the five dimensions of service Journal of Education and Research, August 2016, Vol. 6, No. 2 
quality. The $\mathrm{F}$ statistics produced $(\mathrm{F}=30.97)$ is significant at the 0.00 level. From this result, tangibility (unstandardized coefficients $B$ is -0.04 at sign. $T=0.68$ ), assurance (unstandardized coefficients $\mathrm{B}$ is -0.21 at sign. $\mathrm{T}=0.06$ ), and reliability (unstandardized coefficients $B$ is 0.10 at sign. $T=0.21$ ) were not significantly related with satisfaction.

From the results, it was apparent that two dimensions (empathy and responsiveness) were statistically more significant than other dimensions (tangibility, assurance and reliability). Therefore, it can be perceived that empathy and responsiveness are the two critical components of service quality that contributed most to students' satisfaction; for empathy (unstandardized coefficients $\mathrm{B}$ is 0.27 at sign. $\mathrm{T}=0.00$ ) and responsiveness (unstandardized coefficients $\mathrm{B}$ is 0.18 at sign. $\mathrm{T}=0.04$ ) were significantly related with student satisfaction.

Table 4

BBA and MBA Customer Group Multiple Regression Analyses Results

\begin{tabular}{|c|c|c|c|}
\hline Degree & Model & & Standardized Coefficients \\
\hline & & & $\mathrm{B}$ \\
\hline \multirow[t]{6}{*}{ BBA } & 1 & (Constant) & 0.67 \\
\hline & & Service_Quality & $0.63 * *$ \\
\hline & & R2 & 0.40 \\
\hline & & Adjusted R2 & 0.39 \\
\hline & & $\mathrm{N}$ & 117.2 \\
\hline & & $\mathrm{F}$ & 180 \\
\hline \multirow[t]{6}{*}{ MBA } & 1 & (Constant) & 0.59 \\
\hline & & Service_Quality & $0.55 * *$ \\
\hline & & $\mathrm{R} 2$ & 0.30 \\
\hline & & Adjusted R2 & 0.28 \\
\hline & & $\mathrm{N}$ & 18.57 \\
\hline & & $\mathrm{F}$ & 61 \\
\hline
\end{tabular}

Note: Dependent Variable: Student_Satisfaction; $* * \mathrm{p}<.01$

Table 4 shows that $\mathrm{R} 2=0.397$ (adjusted $\mathrm{R} 2=0.39$ ), i.e. $39.7 \%$ of the variance in students' satisfaction was explained by service quality. The $F$ statistics produced $(F=117.12)$ was significant at the 0.00 level. From the result, it can be perceived that service quality is an antecedent of BBA students' satisfaction in the studied management institution.

In Table 5, the results show that $\mathrm{R} 2=0.40$ (adjusted $\mathrm{R} 2=0.281$ ), i.e. $39.53 \%$ of the variance in students' satisfaction was explained by service quality. The F statistics produced $(\mathrm{F}=18.57)$ was significant at the 0.00 level. From the result, it can be perceived that service quality is an antecedent of MBA students' satisfaction in the studied management institution. Thus, analysing both parts and drawing from Tables 4 and 5, the results showed 
that service quality is a significant antecedent of students' satisfaction at both MBA and BBA levels.

\section{Discussion}

This study examines the influence of 'dimensions of service quality' on students' satisfaction, overall predictability of service quality on student satisfaction and the possible variances of the relationship between service quality and students' satisfaction from the perspective of BBA and MBA students. Consistent with the findings of previous studies (e.g. Bigne et al., 2003; Ham \& Hayduk, 2003), this study found that there is a positive relationship between dimensions of service quality, overall service quality and students' satisfaction. Furthermore, it provides evidence that at both graduate and undergraduate level, service quality is antecedent of students' satisfaction. Also, the relationship between overall service quality and students' satisfaction holds stronger than moderate relationship. Consistent with the findings of Soutar and McNiel (1996), all dimensions play a role in explaining students' satisfaction in the overall model but all the dimensions are not statistically significant.

As we look at the study context, several expert comments have been made regarding the quality of management education in Nepal without proper empirical testing. This study shows that the perceived satisfaction with the management school is above average (mean average percent score $=65 \%$ ) and the perceived service quality is much higher (mean average percent score $=81 \%$ ). The service quality is one aspect of overall quality of management education. It can be safely assumed that there might be other determinants of management students' satisfaction other than service quality like price (Sumaedi, Bakit, $\&$ Metasari, 2011). However, this study shows that the service quality aspect is at a good level.

The study provides evidence that empathy and responsiveness are significantly related with satisfaction, which are critical factors that contribute most to students' satisfaction. Both these findings are supported by the previous study (e.g. O'Neill \& Palmer, 2004). AlsoMaushart (2003) expressed that students' satisfaction is an outcome of their management school experience, which involves their formal and informal interactions with the faculty(as cited in Hasan, Ilias, Rahman, \& Razak, 2008, p. 169). This has been further supported by Clewes (2003) who said that teaching-learning is actually the central part of students' evaluation of service quality. Unfailing to this claim, empathy and responsiveness which are two critical ingredients of human connect have come as significant predictors of students' satisfaction. This is further supported by the study that collectivism is related to dimensions of service quality like courtesy and communication (Malhotra, Ulgado, Agarwal, \& Baalbaki, 1994). As such, Nepali society practices collectivism leading to the importance of responsiveness. Furthermore, people who had higher individualism expected 
Service Quality and Student Satisfaction 55

lower empathy (Dash et al., 2009), and Nepali society is opposite to individualism rightly creating greater need for empathy.

Evidently, the gap present in perception of service quality between developed and developing countries is due to the disparity that prevails in the economic and socio-cultural environment (Malhotra et al., 1994). This in fact contributes to the existing literature as a check of the perception of service quality in countries like Nepal. In fact, this validates the SERVQUAL model and its applications in other cultural settings than where it was originally developed.

\section{Conclusions and Implications}

The main conclusion drawn from this study is that dimension of service quality and overall service quality are positively related to student satisfaction. In this competitive management education arena, schools must focus on managing and enhancing service quality to make its students happy. Among the five dimensions, students' preferred dimensions of service quality were empathy and responsiveness. Thus in totality, the inference of the study is service quality, which is an important determinant of student satisfaction, and empathy and responsiveness are the main dimensions of service quality.

As this study supports the relationship between 'dimensions of service quality', overall service quality and student satisfaction, and also exhibits that the relationship is valid amongst both BBA and MBA students, the findings can have significant practical implications for management schools. Dimensions of service quality, mainly prioritising empathy and responsiveness can be the improvising areas for management schools. Thus, in management schools, the behaviour and attitude of the faculty and service staff will be critical to students' satisfaction. A whole plethora of trainings to employees on being responsive and empathetic towards students can be incorporated. Management of business schools therefore need to create an environment where employees show responsiveness and empathy towards students at all levels for higher level of students' satisfaction.

The findings of this study suggest several avenues for further research. Future studies could examine influence of empathy and responsiveness on students' satisfaction. Future studies could also examine the moderating effect of other variables like students' learning attitude, emotional intelligence, etc. on the relationship between service quality and students' satisfaction.

\section{References}

Acharya, G. P. (2009). Management education in Nepal: Milieu and future track. Tribhuvan University Golden Jubilee Souvenir, 90-95.

Alridge, S., \& Rowley, J. (2001). Conducting a withdrawal survey. Quality in Higher Education, 7(1), 55-63. doi:10.1080/13538320120045085 
56 R. Baniya

Anderson, E., Fornell, C., \& Rust, R. (1997). Customer satisfaction, productivity, and profitability: Differences between goods and services. Marketing Science, 16(2), 129145. doi:10.1287/mksc.16.2.129

Atheeyaman, A. (1997). Linking student satisfaction and service quality perceptions: The case of university education. European Journal of Marketing, 31(7), 528-540. doi:10.11 08/03090569710176655

Bigne, E., Moliner, M. A., \& Sanchez, J. (2003). Perceived quality and satisfaction in multi service organizations: The case of Spanish public services. The Journal of Services Marketing, 17(4), 420-442. doi:1-10.1108/08876040310482801

Bindsardi, A., \& Ekwulugo, F. (2003). International marketing of British education: Research on the students' perception and the UK market penetration. Marketing Intelligence and Planning, 21(5), 318-327. doi:10.1108/02634500310490265

Brady, M. K., \& Cronin Jr, J. J. (2001). Some new thoughts on conceptualizing perceived service quality: A hierarchical approach. Journal of Marketing, 65(3), 34-49. Retrieved from www.jstor.org/stable/3203465

Buttle, F. (1996). What's wrong with SERVQUAL?(Working Paper Series No. 277). Manchester, England: Manchester Business School.

Cardozo, R. N. (1965). An experimental study of customer effort, expectation and satisfaction. Journal of Marketing Research,2, 244-249. doi:10.2307/3150182

Clewes, D. (2003). A student-centred conceptual model of service quality in higher education. Quality in Higher Education, 9(1), 69-85. doi:10.1080/13538320308163

Cranny, C. J., Smith, P. C., \& Stone, E. F. (Eds.). (1992). Job satisfaction: How people feel about their jobs and how it affects their performance. New York, NY: Lexington Books.

Cronin, J. J., \& Taylor, S. A. (1992). Measuring service quality: A reexamination and extension.Journal of Marketing, 56(3), 55-68. doi:10.2307/1252296

Cuthbert, P. F. (1996). Managing service quality in HE: Is SERVQUAL the answer? Part 2. Managing Service Quality: An International Journal, 6(3), 31-35. doi:10.1108/0960452 9610115858

Nitecki, D. A. (1996). An assessment of the applicability of SERVQUAL dimensions as customer-based criteria for evaluating quality of service in an academic library (Unpublished doctoral dissertation). College Park, The University of Maryland, MD.

Dash, S., Bruning, E., \& Acharya, M. (2009). The effect of power distance and individualism on service quality expectations in banking: A two- country individualand national-cultural comparison. International Journal of Bank Marketing, 27(5), 336358. doi:10.1108/02652320910979870

DeCenzo, D. A., \& Robbins, S. P. (2010). Fundamentals of human resource management (10th ed.). Hoboken, NJ: John Wiley \& Sons. 
Service Quality and Student Satisfaction 57

Elliot, K. M., \& Shin, D. (2002). Student satisfaction: An alternative approach to assessing this important concept. Journal of Higher Education Policy and Management, 24(2), 197-209. doi:10.1080/1360080022000013518

Gómez, M., McLaughlin, E., \& Wittink, D. (2004). Customer satisfaction and retail sales performance: An empirical investigation. Journal of Retailing, 80, 265-278. doi:10.1016/j.jretai.2004.10.003

Gronroos, C. (1983). Strategic management and marketing in the service sector. Boston, MA: Marketing Science Institute.

Gruber, T., Fuß, S., Voss, R., \& Gläser-Zikuda, M. (2010). Examining student satisfaction with higher education services: Using a new measurement tool. International Journal of Public Sector Management, 23(2), 105-123. doi:10.1108/09513551011022474

Ham, L., \& Hayduk, S. (2003). Gaining competitive advantages in higher education: analyzing the gap between expectations and perceptions of service quality. International Journal of Value-Based Management, 16(3), 223-242. doi:10.1023/A1025882025665

Hasan, H. F. A., Ilias, A., Rahman, R. A., \& Razak, M. Z. A. (2008). Service quality and student satisfaction: A case study at private higher education institutions. International Business Research, 1(3), 163-175. doi:10.5539/ibr.v1n3p163

Hill, F. M. (1995). Managing service quality in higher education: The role of the student as primary consumer. Quality Assurance in Education, 3(3), 10-21. doi:10.1108/09684889 510093497

Ijaz, A., Irfan, S. M., Shahbaz, S., Awan, M., \& Sabir, M. (2011). An empirical model of student satisfaction: Case of Pakistani public sector business schools. Journal of Quality and Technology Management, 7(11), 91-114.

Katuwal, S. B. (2011). Global financial crisis and higher education in Nepal. International Journal of Business Management, Economics and Information Technology, 3(1), 39-45. Retrieved from http://www.serialsjournals.com/serialjournalmanager/pdf/133066992

K. C., S. (2014).Building quality in management education through institutional development: Perspective from Nepal. Retrieved from https://www.kusom.edu.np/ uploaded/pdf/ConferencePaper-1.pdf

Kitchroen, K. (2004). Literature review: Service quality in educational institutions. $A B A C$ Journal, 24(2), 14-25. Retrieved from http://www.assumptionjournal.au.edu/index.php/ abacjournal/article/view/630/563

Koirala, P. (2005). Vision and mission of management education in Nepal. Tribhuvan University Journal, 25(1), 27-32. Retrieved from https://www.nepjol.info/index.php/ TUJ/article/view/3744/3210 
58 R. Baniya

Kraft, E., \& Vodopoviec, M. (2003). The new kids on the block: The entry of private business schools in transition economies. Education Economics, 11(3), 239-257. doi:10.1080/0964529032000178437

Lassar, W. M., Manolis, C., \& Winsor, R. D. (2000). Service quality perspectives and satisfaction in private banking. Journal of Services Marketing, 14(3), 244-271. doi.org/10.1108/08876040010327248

LeBlanc, G., \& Nguyen, N. (1997). Searching for excellence in business education: an exploratory study of customer impressions of service quality. International Journal of Educational Management, 11(2), 72-79. doi:10.1108/09513549710163961

Lee, H., Lee, Y., \& Yoo, D. (2000). The determinants of perceived service quality and its relationship with satisfaction. Journal of Service Marketing, 14(3), 217-231. doi:10.110 8/08876040010327220

Lehtinen, U., \& Lehtinen, J. R. (1982). Service quality: A study of quality dimensions (Working Paper). Helsinki, Finland: Service Management Institute.

McQuitty, S., Finn, A., \& Wiley, J. B. (2000). Systematically varying customer satisfaction and its implications for product choice. Academy of Marketing Science Review, 10, 116. Retrieved from http://citeseerx.ist.psu.edu/viewdoc/download?doi=10.1.1.127.2240 \&rep $=$ rep1\&type $=$ pdf

Malhotra, N. K., Ulgado, F. M., Agarwal, J., \& Baalbaki, I. B. (1994). A comparative evaluation of the dimensions of service quality between developed and developing countries. International Marketing Review, 11(2), 5-15. doi:10.1108/026513394100619 37

Malik, M. I., \& Usman, A. (2011). Role overload, job satisfaction and their effect on layoff survivor's job retention and productivity. Interdisciplinary Journal of Contemporary Research in Business, 2(11), 427-44440

Nicholls, J., Harris, J., Morgan, E., Clarke, K., \& Sims, D. (1995). Marketing higher education: The MBA experience. The International Journal of Educational Management, 9(2), 31-38. doi:10.1108/09513549510082369

Oliver, R. L. (1980). A cognitive model of the antecedents and consequences of satisfaction decisions. Journal of Marketing Research, 17, 460-469. doi:10.2307/3150499

O’Neill, M. A., \& Palmer, A. (2004). Importance-performance analysis: A useful tool for directing continuous quality improvement in higher education. Quality Assurance in Education, 12(1), 39-52.

Parasuraman, A., Zeithaml, V. A., \& Berry, L. L. (1985). A conceptual model of service quality and its implications for future research. Journal of Marketing, 49(10), 41-50. doi: $10.2307 / 1251430$ 
Service Quality and Student Satisfaction 59

Parasuraman, A., Zeithaml, V. A., \& Berry, L. L. (1988). SERVQUAL: A multiple item scale for measuring consumer perceptions of service quality. Journal of Retailing, 6(1), 12-36.

Berry, L. L., Zeithaml, V. A., \& Parasuraman, A. (1990). Five imperatives for improving service quality. Sloan Management Review, 31(4), 29-38.

Parasuraman, A., Zeithaml, V. A., \& Berry, L. L. (1996). The behavioural consequences of service quality. Journal of Marketing, 60(2), 31-46. doi:10.2307/1251929

Patterson, P. G. (1993). Expectations and product performance determinants of satisfaction for high-involvement purchase. Journal of Psychology and Marketing, 10(5), 449-465. doi:10.1002/mar.4220100507

Perisau, S. E., \& McDaniel, J. R. (1997). Assessing service quality in schools of business. International Journal of Quality and Reliability Management, 14(3), 204-218. doi:10.11 08/02656719710165455

Rigotti, S., \& Pitt, L. (1992). SERVQUAL as a measuring instrument for service provider gaps in business schools. Management Research News, 15(3), 9-17. doi:10,1108/ eb028197

Robinson, S. (1999). Measuring service quality: Current thinking and future requirements. Marketing Intelligence \& Planning, 17(1), 21-32. doi:10.1108/02634509910253777

Rosenbloom, A., \& K.C., B. (2005). Management education in Nepal: A view from the high country. In J. R. Mclntyre \& I. Alon (Eds.), Business and management education in transitioning and devloping countries: A handbook (pp. 69-84). New York, NY: M.E. Sharpe.

Rust, R., Zahorik, A., \& Keiningham, T. (1995). Return on quality (ROQ): Making service quality financially accountable. Journal of Marketing, 59, 58-70. doi:10.1007/978-3322-96503-5_36

Saaditul, I., Shamsinar, M. S., \& Wong, C. M. (2000). Customer satisfaction towards service quality of higher education in Malaysia. Paper presented at the FEP Seminar, 20 - 23 October 2000, Pulau Pinang, Malaysia.

Sasser, W. E., Olsen, R. P., \& Wyckoff, D. D. (1978).Management of service operations. Boston, MA: Allyn \& Bacon.

Soutar, G. N., \& Turner, J. P. (2002). Students' preferences for university: A conjoint analysis. The International Journal of Educational Management, 16(1), 40-45. doi:10.1 108/09513540210415523

Soutar, G. N., \& McNeil, M. (1996). Measuring service quality in a tertiary institution. Journal of Educational Administration, 34(1), 72-82. doi:10.1108/09578239610107174 
Spreng, R., \& Mckoy, R. (1996). An empirical examination of a model of perceived service quality and satisfaction. Journal of Retailing, 72, 201-214. doi:10.1016/S00224359(69)90014-7

Sumaedi, S., Bakit, I. G. M. Y., \& Metasari, N. (2011). The effect of students' perceived service quality and perceived price on student satisfaction. Management Science and Engineering, 5(1), 88.

Wilson, A., Zeithaml, V. A., Bitner, M. J., \& Gremler, D. D. (2008). Services marketing. New York, NY:McGraw-Hill Education.

Woo, K., \& Ennew, C. T. (2005). Measuring business-to-business professional service quality and its consequences. Journal of Business Research, 58, 1178-1185. doi:10.1016/j.jbusres.2004.05.003 


\section{Appendix: Questionnaire}

Year:

Semester:

Gender: $\mathrm{M} / \mathrm{F}$

Age:

The questions are designed to understand students' perceptions on the quality of services provided by your school. So, please indicate whether you agree or disagree with the following statements by tick marking in the appropriate boxes.

\begin{tabular}{|c|c|c|c|c|c|c|c|}
\hline & \multirow[b]{2}{*}{ Questions } & \multicolumn{2}{|c|}{$\begin{array}{l}\text { Strongly } \\
\text { Disagree }\end{array}$} & \multicolumn{2}{|c|}{ Neutral } & \multicolumn{2}{|c|}{$\begin{array}{c}\text { Strongly } \\
\text { Agree }\end{array}$} \\
\hline & & 1 & 2 & 3 & 4 & 5 & 6 \\
\hline & Tangibility & & & & & & \\
\hline 1. & The lecturers are well dressed and friendly. & & & & & & \\
\hline 2. & $\begin{array}{l}\text { The interiors of the classrooms are study } \\
\text { friendly. }\end{array}$ & & & & & & \\
\hline 3. & $\begin{array}{l}\text { The classrooms are well lit and well } \\
\text { ventilated. }\end{array}$ & & & & & & \\
\hline 4. & $\begin{array}{l}\text { My school building looks good and it has } \\
\text { sufficient playground. }\end{array}$ & & & & & & \\
\hline 5. & $\begin{array}{l}\text { The overall cleanliness of the university is } \\
\text { satisfactory. }\end{array}$ & & & & & & \\
\hline 6. & $\begin{array}{l}\text { The classrooms and study rooms are } \\
\text { comfortable. }\end{array}$ & & & & & & \\
\hline 7. & $\begin{array}{l}\text { My school's atmosphere and decoration of } \\
\text { the building is impressive. }\end{array}$ & & & & & & \\
\hline 8. & The staffs are well dressed and friendly. & & & & & & \\
\hline 9. & My School has sufficient parking space. & & & & & & \\
\hline 10. & $\begin{array}{l}\text { My school's course structure is regularly } \\
\text { updated. }\end{array}$ & & & & & & \\
\hline 11. & $\begin{array}{l}\text { My school offers variety of courses as per the } \\
\text { requirement. }\end{array}$ & & & & & & \\
\hline 12. & $\begin{array}{l}\text { Computer lab has enough computers to meet } \\
\text { the needs of the students. }\end{array}$ & & & & & & \\
\hline 13. & $\begin{array}{l}\text { The computers in the lab are regularly } \\
\text { updated. }\end{array}$ & & & & & & \\
\hline 14. & $\begin{array}{l}\text { The software in the computers is regularly } \\
\text { updated. }\end{array}$ & & & & & & \\
\hline
\end{tabular}




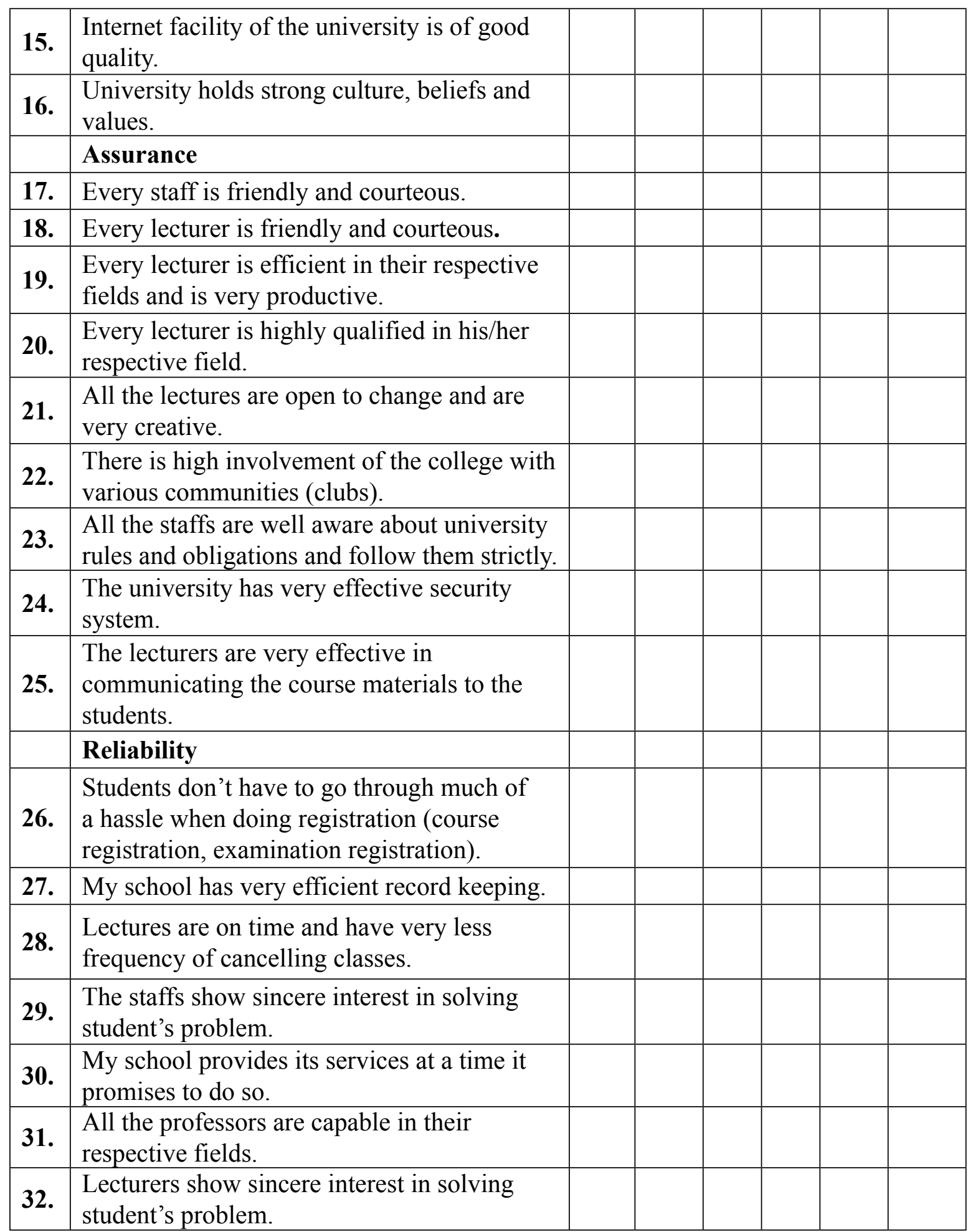




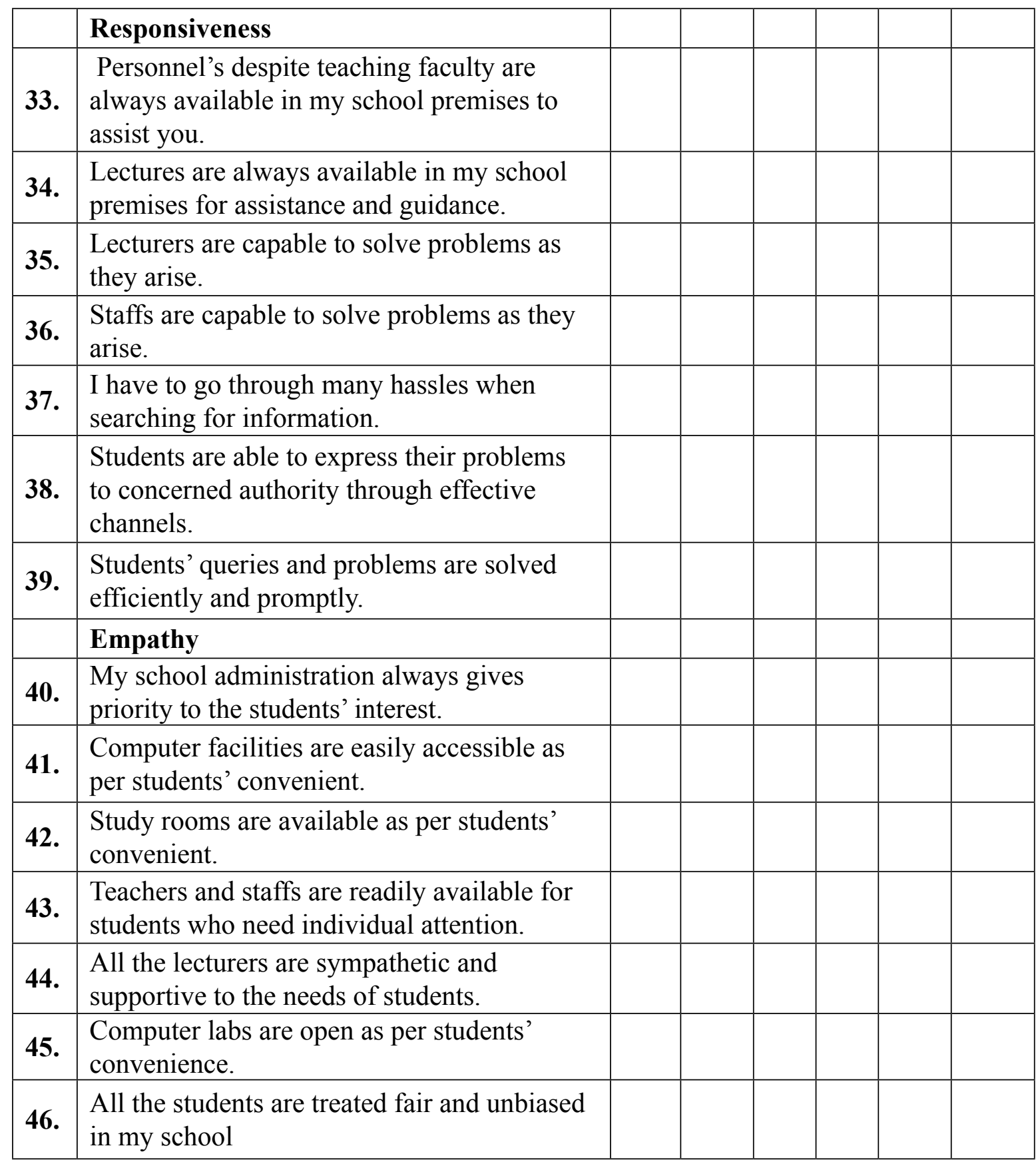

The below questions are designed to check the satisfaction level of the students based on the above service qualities of your school. So, please indicate whether you agree or disagree with the following statements by tick marking in the appropriate boxes. 


\begin{tabular}{|l|l|l|l|l|l|l|l|}
\hline & \multicolumn{1}{|c|}{$\begin{array}{c}\text { Strongly } \\
\text { Qisagree }\end{array}$} & \multicolumn{2}{c|}{ Neutral } & \multicolumn{2}{c|}{$\begin{array}{c}\text { Strongly } \\
\text { Agree }\end{array}$} \\
\hline & \multicolumn{1}{|c|}{ Students Satisfaction } & & & & & & $\mathbf{6}$ \\
\hline 1. & $\begin{array}{l}\text { I am happy with my decision of } \\
\text { attending my school. }\end{array}$ & & & & & & \\
\hline 2. & $\begin{array}{l}\text { I will again enrol in my school; if } \\
\text { I am give a chance to start all over } \\
\text { again. }\end{array}$ & & & & & & \\
\hline 3. & $\begin{array}{l}\text { I made a wise decision by enrolling } \\
\text { in my school. }\end{array}$ & & & & & & \\
\hline 4. & $\begin{array}{l}\text { I am happy with my decision to } \\
\text { study in my school. }\end{array}$ & & & & & & \\
\hline 5. & $\begin{array}{l}\text { I made a right decision by choosing } \\
\text { my school. }\end{array}$ & & & & & & \\
\hline 6. & $\begin{array}{l}\text { I am happy that I got admitted in } \\
\text { my school. }\end{array}$ & & & & & & \\
\hline
\end{tabular}

